\title{
ACASO, DESCASO, CASOS DE CRÔNICAS DE MORTES ANUNCIADAS: ENREDANDO FEMINICÍDIO, PATRIARCADO E EDUCAÇÃO*
}

\author{
Adriana A. Silva \\ Ana Lúcia Goulart de Faria
}

\begin{abstract}
Resumo
O presente ensaio tem como cenário a América Latina contemporânea, território complexo de territorialidades que marcam a tragédia colonial. A partir de um jogo entrelaçado de narrativas em diversas linguagens, partimos do documentário Quem matou Eloá? (BRASIL, 2015), que expõe a cultura da violência, sobretudo a patriarcal, sustentada pela mídia, passando por alguns crimes que chocaram o país. Como interlocuções literárias, evocamos os livros de ficção Garotas Mortas, da argentina Selva Amada, e Mulheres Empilhadas, da brasileira Patrícia Melo, ambas publicações emergentes e urgentes, de 2018 e 2019, respectivamente. Relatos pungentes de crimes bárbaros, mas cotidianos, cometidos contra as mulheres latino-americanas. Visualizamos também nesta historiografia contemporânea narrativas visuais de denúncias e reexistências das mulheres da Cidade Juarez, no México, com a instalação dos Zapatos Rojos, de Elina Chauvet, à performance Un violador en su caminho, do coletivo chileno Las teses, ambos dispositivos políticos de corpos em aliança (BUTLER, 2019), que "viralizaram" em praças e telas da internet ao redor do mundo. Até chegarmos aos levantes populares em meio à pandemia de Vidas negras importam, desencadeados pelo assassinato de George Floyd, nos Estados Unidos, que nos relembram as balas perdidas que mataram Agatha e muitas outras crianças, com suas vidas ameaçadas (ARROYO, 2019) ou exterminadas como o menino Miguel, "negligenciado" pela patroa da mãe no Recife, à execução de Marielle Franco.
\end{abstract}

Inspiramo-nos - neste processo terapêutico, narrativo e historiográfico -, em uma mulher, personagem clássica, que, do seu medo de morrer, inventou a arte de narrar: Sherazade, por Eduardo Galeano, no belíssimo livro Mulheres:

Para se vingar de uma, que o havia traído, o rei degolava todas. No crepúsculo se casava, na alvorada enviuvava. Uma atrás da outra, as virgens perdiam a virgindade e a cabeça. Sherazade foi a única que sobreviveu à primeira noite, e depois continuou trocando uma história por cada novo dia de vida. Essas histórias, por elas escutadas, lidas ou imaginadas, a salvavam da decapitação. As dizia em voz baixa, na penumbra do quarto, sem outra luz que a da lua. Dizendo essas histórias sentia prazer, mas tomava muito cuidado. Às vezes, em pleno relato, sentia que o rei estava examinando seu pescoço. Se o rei se aborrecesse, estava perdida. Do medo de morrer nasceu a maestria de narrar. (GALEANO, 2019, p.07).

\footnotetext{
* DOI - 10.29388/978-65-86678-51-2-0-f.603-622
} 


\title{
Acaso, descaso e casos em narrativas: poéticas da memória
}

Garotas mortas (2018), de Selva Almada, é um livro dedicado à memória de Andrea, María Luisa e Sarita - três jovens mulheres assassinadas no interior da Argentina, na década de 1980. Andrea Danne tinha 19 anos e foi assassinada com uma única apunhalada no coração, enquanto dormia. Maria Luisa Quevedo, 15 anos, foi estuprada, estrangulada e abandonada em um terreno baldio. Sarita Mundín tinha 20 anos quando desapareceu; seu esqueleto foi encontrado nove meses depois, ao acaso, preso entre os galhos de uma árvore, às margens de um rio.

Três feminicidios - na época não se usava esta nomenclatura - conquista legal recente, após a luta política do feminismo transnacional. Três mortes sem culpados, histórias aterradoras, que a autora e jornalista, instigada pelo descaso nas investigações, busca por conta própria reconstruir e compreender casos que nos atravessam a existência, como nos alerta a antropóloga argentina Rita Segato, em Território, soberania e crimes de segundo Estado: a escritura nos corpos das mulheres de Ciudad Juarez, corpo de mulher, perigo de morte (SEGATO, 2013).

Em sua busca e relato, Selva Almada nos apresenta como se deparou com a questão, ao ouvir distraidamente no rádio, na manhã de 16 de novembro de 1986, em meio ao churrasco de domingo ao lado do pai, que naquela madrugada, em uma cidadezinha vizinha de onde morava, uma adolescente tinha sido assassinada em sua própria cama enquanto dormia. Ela e o pai permaneceram em silêncio, continuaram o churrasco, mas foi naquele momento que ela teve a terrível revelação

\begin{abstract}
Minha casa, a casa de qualquer adolescente, não era o lugar mais seguro do mundo. Você podia ser morta dentro da sua própria casa. O horror podia viver sob o mesmo teto. Nos dias seguintes, conheci mais detalhes. A garota se chamava Andrea Danne, tinha dezenove anos, era loira, bonita, de olhos claros, estava namorando e fazendo um curso de psicologia. Tinha sido assassinada com uma punhalada no coração.
\end{abstract} (ALMADA, 2018, p. 12)

Ao longa da sua narrativa, vai enredando acasos, descaso e os três casos em rememoração, reconstruindo-os a partir da mídia e dos processos jurídicos, das suas memórias e dos familiares das vítimas, buscando compreender, nos rastros do passado, um fenômeno que assola o presente: crimes sem responsáveis.

Em uma passagem do livro, a autora procura uma cartomante, salientando que, em dois dos três casos, familiares consultaram videntes, porém, as experiências não acrescentaram nada à resolução dos casos; questiona-se que talvez não fosse o tempo ideal, cedo na busca das famílias, tarde na da autora, após tantos anos dos crimes. A cartomante lhe diz:

Nunca é tarde. Mas eu acho que no além tudo deve estar junto e enredado, como um novelo de lã. É preciso ter paciência e ir puxando a ponta bem devagar. Você conhece a história de La Huesera, a Mulher dos Ossos?

Faço que não com a cabeça.

É uma velha muito velha que vive em certo esconderijo da alma. Uma velha chucra que cacareja como as galinhas, canta como os pássaros e emite sons mais animais do que humanos. Sua tarefa consiste em catar ossos. Ela recolhe e guarda tudo aquilo 
que periga se perder. Sua choupana está cheia de ossos de todo tipo de animais. Mas os preferidos são os ossos dos lobos. Para encontrar um, ela é capaz de caminhar por quilômetros e mais quilômetros, galgar montanhas, atravessar rios, queimar a sola dos pés nas areias do deserto. De volta à sua choupana com a braçada de ossos, ela monta o esqueleto. Quando La Huesera põe a última peça no lugar e a figura do lobo resplandece diante de seus olhos, ela se senta junto ao fogo e se põe a pensar que canção cantará. Quando se decide, ergue os braços sobre o esqueleto e principia seu canto. À medida que canta, os ossos vão se forrando de carne; e a carne, de couro; e o couro, de pelos. Ela continua a cantar, e a criatura ganha vida, começa a respirar, seu rabo se estica, abre os olhos, dá um salto e sai correndo da choupana. A certa altura da sua corrida vertiginosa, seja pela velocidade, seja porque mergulha nas águas de um rio para atravessá-lo, seja porque o luar o apanha em cheio num flanco, o lobo se transforma numa mulher que corre livremente rumo ao horizonte, rindo às gargalhadas.

Talvez seja esta a sua missão: recolher os ossos das garotas, armá-las, dar-lhes voz e depois deixá-las correr livremente para onde tiverem que ir. (ALMADA, 2018, p. 3334)

\section{Poéticas da resistência: esquecidas, empilhadas a enfurecidas}

Esquecer e lembrar, um jogo ou um convite à potência do lembrar para reparar, parar um massacre em curso, o genocídio de mulheres que na base do horror e medo sustenta o sistema capitalista patriarcal (FEDERICI, 2017, 2019), em uma opressão indissociável de dominação-exploração (SAFIOTTI, 2015).

Lembrar que é a partir de narrativas ficcionais e midiáticas que vão enredando histórias de mulheres-meninas (SILVA, 2002). De meninas-mulheres submissas e condenadas a empoderadas amazonas lendárias, à espreita em referências "ao acaso" que nos conduz a experimentar uma possível "historiografia terapêutica" do feminicídio, buscando responder, compreender, instigar a reflexão acerca de quem matou, ou melhor, como nos incita a literatura: porque se matam mulheres como moscas?

Em "Mulheres Empilhadas" (2019), romance da escritora brasileira Patricia Melo, é ressaltado que, embora se trate de uma obra de ficção, suas personagens existem de fato, são mulheres protagonistas da história que estão nas páginas do livro, como nunca estiveram nos pouquíssimos livros que ousaram falar das mulheres, todas as mulheres, em toda sua potência e diversidade.

E todas nós: as mulheres já feitas e as meninas, as mais velhas e as mais novas, as gordas e as magras, as negras e as pardas, as indígenas e as descendentes de imigrantes, as urbanas e as do campo, as analfabetas e as com grau universitário, as faxineiras, as professoras, as ambulantes, as atrizes, as costureiras, as engenheiras, as designers e as que não trabalham fora, as solteiras, as casadas, as divorciadas, as lésbicas, as trans, as mães, as filhas, as avós, as tias, as irmãs e as primas. Pertencemos a mesma família. Em nosso sangue, em nossas veias ou derramado no chão, ainda corre a força do patriarcado, da violência e do medo que só uma mulher sente e que atravessa gerações. (MELO, 2019, contracapa)

A autora, que tem diversos livros publicados, salienta que em geral a escritura de seus romances é uma trilha solitária, mas, neste caso, teve o suporte e a assistência de muitos amigos e profissionais, especialmente na área jurídica e no campo dos Direitos Humanos. A narrativa vai de A a Z, passa-se no Acre, não por acaso, pois é um território 
marcado atualmente com um dos maiores índices de feminicídio no Brasil. A história acompanha uma jovem advogada do sudeste que, ao ser agredida pelo namorado, em uma festa de advogados, final de ano, vê-se imersa em uma cruel trama de feminicídios, envolvendo a sua história familiar e a das mulheres empilhadas de 1 (primeira vítima): "MORTA PELO MARIDO. Elaine Figueiredo Lacerda, sessenta e um anos, foi abatida a tiros na porta de sua casa, num final de tarde de domingo." (MELO,2019, p.09-12) (p.09) a 12 (décima segunda vítima).

\section{DA SIMPLES ARTE DE MATAR UMA MULHER}

No topo da pilha das minhas mulheres mortas, na altura do hipocôndrio direito, ou mais especificamente a meio caminho entre o mamilo direito e o umbigo, no corpo de Carla Penteado, 40 anos, (independente, vacinada e dona do seu nariz) foi identificado um ferimento ovalar uniforme de bordos contínuos, invertidos, avermelhados, produzidos por passagem de projétil de arma de fogo. (MELO, 2019, p. 194)

Doze mulheres, dentre muitas outras que figuram soltas e em destaque na narrativa como fantasmagorias de uma sucessão de horror, crueldade e impunidade banal. A advogada, fugindo de um namorado agressor, no escritório de Direito no qual trabalha, consegue se deslocar para acompanhar, no norte do país, um mutirão de julgamentos de crimes contra as mulheres, visando colher informações a respeito do fenômeno, a fim de publicar um livro.

Nessa viagem, ao se deparar com os processos, encontra mulheres empilhadas, enredadas em milhares de crimes marcados pela banalidade presente nas descrições de agressões desde redes da violência doméstica até a fatalidade permissiva patriarcal dos feminicídios. As mulheres são agredidas, violentadas e assassinadas porque o sistema social que nos organiza a vida permite, porém, dialeticamente, também nos incita a resistirmos.

As mulheres empilhadas no mutirão de julgamentos do Acre incitam metaforicamente a literatura de Patrícia Mello e o empoderamento de sua protagonista, que, contagiada pelas lendas amazônicas, vivencia os poderes da floresta, de cura e de justiça, resgatando no movimento narrativo a força e a potência dos corpos femininos, das vidas que pulsam com e entre as mulheres.

Flap, flap, flap, no céu, as bocetas voavam juntas com a passarada que anuncia o verão. Bocetas-araras, bocetas-gaviões papa-gafanhoto, bocetas-bico-encarnado. E bocetas-bem-te-vi, bocetas-pariri, bocetas-sucuruá-de-barriga-vermelha. E bocetasfruxus-de-barriga-amarela, bocetas-pinto-do-mato, bocetas-uiraçu-falso, bocetasjaipim-da-selva. Eram tantas e tão coloridas, umas encabeçando formações em v, outras solitárias, planando no céu azul. E as mulheres também não pararam de chegar. Algumas voando. Outras nadando. Aquelas cavalgando. Estas patinando. Eu, caminhando devagar, olhando bem onde pisava, ora no fogo, ora no gelo, ora sobre as águas. Algumas mulheres estavam nuas. Outras possuíam uma tarja-preta como tapa-sexo, melhor dizendo, um cinto de castidade. E essas, as tarjadas, conforme se alinhavam ao redor do lago, recebiam suas bocetas de volta, bocetas que chegavam voando. Flap, flap, clic. Digo, nossas bocetas simplesmente se encaixavam em nós com um clique automático, liberando-nos da tarja-preta-tapa-sexo-cinto-decastidade. Txupira (adolescente indígena que é brutalmente assassinada por três jovens poderosos da cidade no início da trama), entre nós, contava que seu caso fora diferente. Sua boceta não voltara voando, como as outras. Horas antes, Txupira 
encontrara seu sexo jogado numa pilha onde se lia "bocetas rosas". Para vender? Perguntou uma. A mais alta explicou que sim. -No mercado das bocetas, as rosas têm grande valor. -Por isso nossas vaginas estão sendo operadas - disse esta. Recortam nossos grandes lábios - afirmou aquela. -Reduzem nosso Monte de Vênus - completou outra. -Clareiam nossa xoxota - completou a mais alta. Todas juntas: Esses açougueiros! -Esses carniceiros! Eu disse: -Caçam nossas bocetas com puçá. Como se fossemos borboletas. Txupira: -Nada incomoda mais do que uma boceta independente! (MELO, 2019, p. 202-203)

Enredadas na teia de vida, morte e mulheres enfurecidas figuram las mariposas, como eram conhecidas as irmãs Mirabal, brutalmente assassinadas em 25 de novembro ${ }^{1}$ de 1960, três militantes contra a ditadura na República Dominicana; tornaram-se símbolo de luta da violência contra as mulheres. Potências da resistência que pairam como borboletas apavoradas, alertando contra os crimes cometidos contra as mulheres e meninas pelo mundo, em todas as partes do planeta, diariamente, temos narrativas de feminicídios bárbaros, mulheres mutiladas, violentadas, esquartejadas, desaparecidas, esquecidas? (TELES, 2017)

\section{Pedagogias da crueldade: enredando feminicídio, patriarcado e educação}

Segundo relatório da ONU, 87 mil mulheres morreram em 2017, vítimas de feminicídio. 58\% delas foram assassinadas por conhecidos - seus companheiros, exmaridos ou familiares. O documento, elaborado pelo Escritório das Nações Unidas contra a Droga e o Crime (Onudd), indica que o assassinato de mulheres por parte dos seus companheiros faz com que o lar seja o "lugar mais perigoso para as mulheres" e "é frequentemente a culminação de uma violência de longa duração e pode ser prevenida".

"O melhor dia da minha vida foi quando eu conheci a Ágatha. O pior foi quando eu a matei", diz Jhony Marcos Barcelos de Souza, 27, preso há três anos no Centro de Detenção Provisória da Serra, no interior do Espírito Santo. Feminicida confesso, ele assassinou a companheira a golpes de picareta, quando ela anunciou a intenção de se separar. ${ }^{2}$

Os alarmantes índices de feminicídio no Brasil refletem o desfecho trágico de um processo colonizador que tem na cultura da violência a base estrutural das relações de poder, ou seja, uma violência patriarcal'. Mata-se por 'amor', pela força que o homem tem no corpo e na vida das mulheres, um direito secular de posse, construída historicamente

\footnotetext{
${ }^{1}$ Em homenagem à luta das irmãs Mirabal, o $1^{\circ}$ Encontro de Mulheres da América Latina e Caribe, realizado em 1981, em Bogotá, decidiu criar o Dia Internacional da Não Violência contra a Mulher na data de $\mathbf{2 5}$ de novembro de cada ano. Para saber mais sobre a história das irmãs Mirabal, o filme No tempo das borboletas (2001), baseado no livro homônimo escrito em 1994 por Julia Álvarez, retrata o período de ditadura militar (1930-1961) na República Dominicana, onde por 31 anos o povo esteve refém das atrocidades cometidas pelo general Rafael Leónidas Trujillo. Sob seu lema ou estás comigo ou contra mim, e com o beneplácito da Igreja, Trujillo mandava matar todos os que se opunham ao seu regime. Foi responsável direto pelo assassinato de mais de 30 mil pessoas. Fonte: https://averdade.org.br/2011/11/no-tempo-dasborboletas/ Acesso em: 01 ago. 2020.

2 "O melhor dia da minha vida foi quando a conheci. O pior, quando eu a matei". Disponível em (https://brasil.elpais.com/brasil/2019/08/16/politica/1565961105_327484.html)_Acesso 01/08/2020.

${ }^{3}$ Em um precioso ensaio intitulado "Pelo fim da violência", bell hooks (2018), (intelectual negra estadunidense, teórica feminista, crítica cultural, artista e escritora) defende o termo "violência patriarcal" para problematizar a cultura da violência que estrutura as relações de poder na sociedade capitalista.
} 
pelas narrativas religiosas, legitimadas pelo estado e sustentadas por projetos educacionais e suas pedagogias colonizadoras. Fica a pergunta: uma vez que $90 \%$ da educação e do cuidado das crianças são realizados pelas mulheres, estas pedagogias fundamentalmente machistas estão sendo simplesmente reproduzidas?

$\mathrm{Na}$ perspectiva de compreender as violências contra as mulheres no âmbito estrutural, encontramos, nas análises da antropóloga argentina Rita Segato (2013, 2014), importantes considerações dessa violência estrutural e as pedagogias da crueldade que tangenciam esse fenômeno de ordem global. Segundo Segato (2014), a violência estrutural tem nas guerras suas facetas mais explícitas, porém, assume formas híbridas e configurações múltiplas na atualidade. Nesta direção, destaca um novo cenário bélico mundial, que tem a guerra como meio e fim de exploração e dominação econômica.

E nesse "mercado" bélico, o corpo das mulheres se configura como um importante território de destruição, com excessos de crueldade e tortura sem precedentes na história das guerras. Segato (2014) ressalta que o contexto do neoliberalismo estrutura as novas perversas relações de poder, reconfigurando a territorialidade, a política, o estado, a economia e o próprio patriarcado, com novas configurações dos conflitos informais de guerras não convencionais que se expandem pelo mundo, mas especialmente explodem na América Latina, com o crime organizado, as guerras repressivas do estado e das milícias, a repressão policial, todo um aparado repressivo e truculento.

Rita Segato, que hoje assume umas das vozes mais importantes da luta feminista, salienta o quanto, apesar das conquistas legais, das vitórias no campo das políticas públicas, a vulnerabilidade perante a violência depredadora contra os corpos femininos ou feminizados tem aumentado. O marco do ponto de vista dos conflitos bélicos foram as guerras na Iugoslávia e em Ruanda, nas quais a violência sexual passou de danos colaterais, como historicamente sempre ocorria nas guerras, a assumir uma posição central como arma de guerra.

Nesta perspectiva, Segato salienta que a truculência vai se constituindo como fundamental nas relações de controle e manutenção dos corpos e territórios, tendo a pedagogia da crueldade como a estratégia de reprodução do sistema. Especialmente a crueldade em corpos frágeis - feminino ou feminizados- tem a função de demarcar e potencializar a dominação que é inerente e indissociável a todos os tipos de violência de gênero, porém, como afirma Rita Von Hundy ${ }^{4}$ : "A mulher não é um centro de reabilitação".

O corpo das mulheres é território simbólico de vitória nas disputas da ordem patriarcal nestas novas configurações de informalidade, em que a imposição do mais forte "se escreve" na subjugação do corpo feminino. Toda violência tem uma dimensão instrumental e outra expressiva; a violação sexual tem uma finalidade expressiva e coletiva, trata-se de uma outra finalidade em relação aos crimes de gênero, envolvendo violência doméstica e intimidade, porém, a estrutura patriarcal permanece com determinações de violências às mulheres associadas às facções, aos grupos rivais ou que se pretendem exterminar.

\footnotetext{
${ }^{4}$ Rita Von Hundy é o nome artístico de Guilherme Terreri Lima Pereira, que é ator, YouTuber - tem um canal chamado Tempero Drag, é comediante, professor e drag queen brasileiro. No vídeo Mulher: centro de reabilitação apresenta importantes reflexões sobre os processos de exploração - opressão sobre as mulheres. Fonte: https://www.youtube.com/watch?v=OEr0kbUrNUs Acesso em: 01 ago. 2020.
} 
A defesa de Segato (2014) para crimes cometidos contra as mulheres em contextos de conflitos territoriais é que não são crimes de motivação sexual, mas sim de crimes de guerra, que devem ser analisados com novas lentes, visando incorporar novas categorias jurídicas do campo do Direito e especialmente dos Direitos Humanos e da justiça humanitária internacional.

Da mesma maneira, nas análises de como as crianças são usadas como recursos humanos, mão de obra barata, descartável na manutenção das atividades ilegais que desencadeiam os conflitos bélicos nos grandes centros urbanos. A ordem econômicamilitar que atua nesse cenário informal e subterrâneo da segunda realidade depende de processos de desumanização deliberada e sistemática, com requintes de exibição de crueldade como garantias de controle territorial.

Figura 1 - A menina Ágatha Vitória Sales Félix, de 8 anos, foi morta quando voltava para casa com a mãe, na noite de sexta-feira, 20/09/2019, no Complexo do Alemão, na Zona Norte do Rio. PMs atiraram contra uma moto que passava pelo local, e o tiro atingiu a criança. $(\text { sic })^{5}$

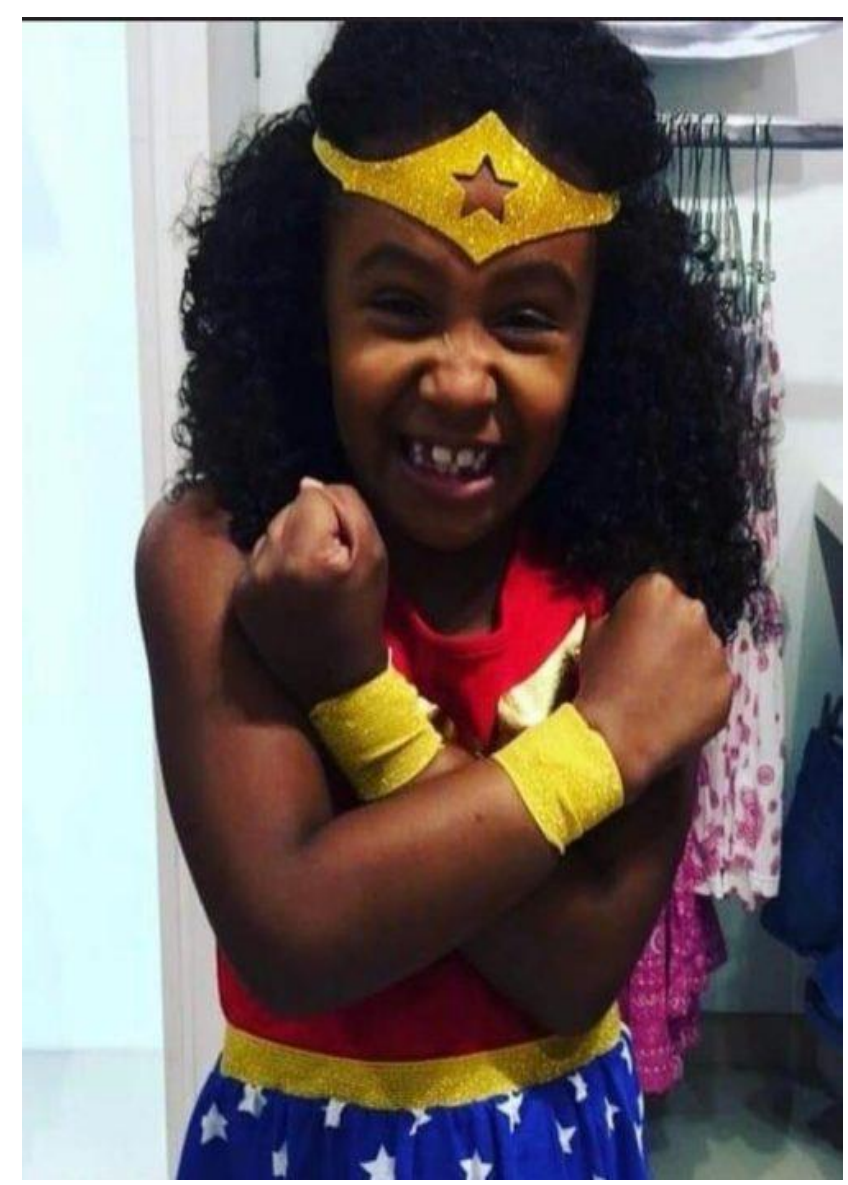

Ágatha Vitória Sales Félix.

Foto: Reprodução

Fonte: Gazeta do povo. ${ }^{6}$

\footnotetext{
${ }^{5}$ Entenda como foi a morte da menina Agatha no Complexo do Alemão, segundo a família e a PM.

(https://g1.globo.com/rj/rio-de-janeiro/noticia/2019/09/23/entenda-como-foi-a-morte-da-menina-agatha-nocomplexo-do-alemao-zona-norte-do-rio.ghtml). Acesso em: 01 ago. 2020.

6 https://www.gazetadopovo.com.br/republica/quem-era-agatha-felix-a-menina-atingida-por-um-tiro-no-complexo$\underline{\text { do-alemao }}$
} 
Disputa pelos corpos - territórios das mulheres, com políticas de subjetividades que são atravessadas por novas realidades jurídicas de várias ordens: empresariaiscorporativas, político-identitárias, religiosas, bélico-mafiosas. Com esse processo de dor e de horror, refletimos em como a cultura da violência, violência patriarcal, que é a base estrutural do capitalismo, apresenta um perverso projeto político-pedagógico de extermínio, genocídio e desumanização de uma grande parcela da população, os excluídos da história, descartáveis: jovens negros, mulheres negras, as mulheres que dizem não, crianças sem pais ou donos. ${ }^{7}$

Figura 2 - As mães ‘órfãs’ de filhos que o Estado levou ${ }^{8}$

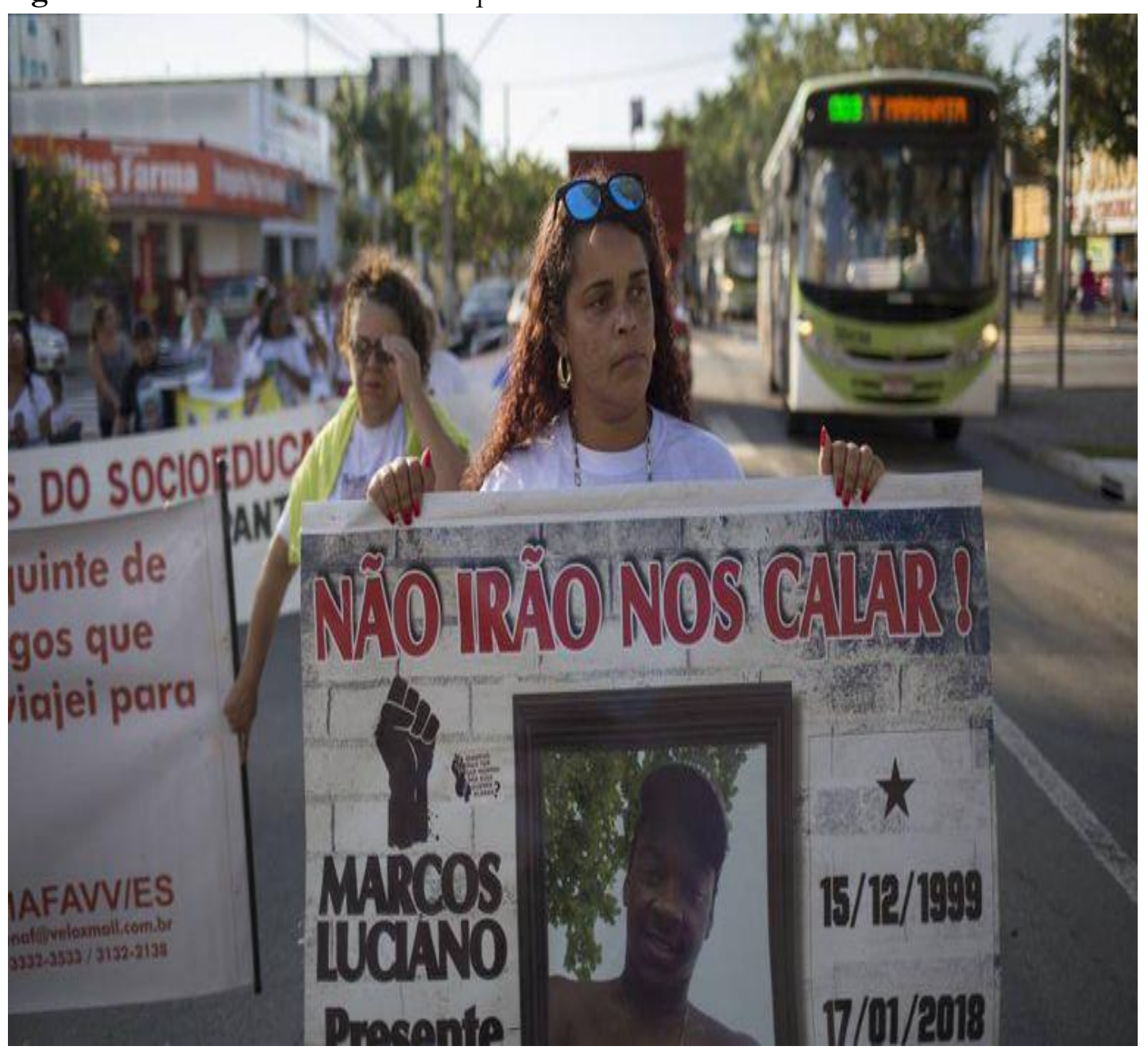

Grupo de mães protestam no centro de Goiânia.

Foto: Toni Pires

Fonte: El país Brasil

Nos últimos anos, deparamo-nos com o acirramento no debate público de uma velha crença que sustenta a ideologia capitalista, amalgamando a tríade fundamental e

\footnotetext{
${ }^{7}$ Parafraseando o fragmento final do clássico curta-metragem Ilha das Flores (1989), de Jorge Furtado, que em off narra as mulheres e crianças miseráveis no lixão, buscando alimentos deixados pelos porcos, salientando que o fato dos seres humanos estarem depois dos porcos na escolha dos alimentos é por não terem dinheiro nem dono, que uma das coisas que diferencia os humanos dos animais é de sermos livres, mas a liberdade é um estado, com condições históricas. 8 https://brasil.elpais.com/brasil/2019/06/10/politica/1560155313_626904.html Acesso em:30 jul. 2020.
} 
intocável: família-tradição-propriedade. Os chamados para "defendemos nossos filhos", a defesa que exalta: "sim à família tradicional", "a família salvará o mundo", "vamos defender nossas crianças" tiveram apoio de várias correntes de fé, como cristãos católicos e evangélicos, muçulmanos e judeus, alastrando-se por toda a América Latina, território de contínuo processo de disputa colonial. ${ }^{9}$

Nessa disputa, não são os filhos de todos que estão sob proteção familiar, pois os laços entre tradição e propriedade que amalgamam tais relações estão diretamente atrelados a questões de ordem econômica, um prisma perverso com muitos lados e interesses: de herança, mão de obra excedente, exército consumidor e alvos da necropolítica que extermina jovens negros nas periferias urbanas.

A partir desta perspectiva de análise da realidade, com sua conjuntura política de acirramento de conflitos de interesses privados que ameaçam um processo histórico de conquista de direitos, direitos humanos conquistados com muitas lutas, sobretudo lutas das mulheres perante as situações-limites que vivenciam em suas existências marcadas pela opressão - exploração perante um sistema - capitalista, patriarcal que explicitamente ou subliminarmente as compreende como escravas domésticas, sexuais, procriadoras, deparamo-nos com constantes desafios de como podemos desconstruir coletivamente essa lógica perversa de base das relações sociais e culturais?

Especialmente na educação da infância, nos processos de formação de professoras, a grande maioria na Educação Infantil, primeira etapa da Educação Básica, e nos anos iniciais do Ensino Fundamental, são mulheres, e historicamente responsáveis pelos trabalhos dos cuidados e da reprodução da vida, trabalho marcado pela invisibilidade, desvalorização, repleto de mitos como o do amor materno e do dom, ou vocação (SILVA, 2015). Como desconstruir as narrativas de manipulação subjetiva que envolvem as mulheres na manutenção de seus processos de opressão, dominação e exploração, ou mesmo de reprodução das pedagogias do horror: machistas, sexistas, racistas, elitistas, adultocêntricas, excludentes que sustentam o sistema?

Nos últimos quarenta anos, avançamos na conquista de direitos, especialmente das mulheres, e buscamos avançar na área da educação, no que se refere à educação das crianças, na busca por novas pedagogias - da escuta, das relações, da diferença, da sensibilidade perante as múltiplas linguagens que as crianças praticam desde que nascem. Porém, ainda que pesquisemos a infância em sua dimensão pública, escolar, institucional e defendemos os direitos das crianças, pouco debatemos acerca da violência cotidiana que as assolam, especialmente nos contextos privados.

Nessa perspectiva, cabe destacar os desafios que temos perante a compreensão das complexidades da máquina patriarcal, ou seja, a estrutura que fundamenta as relações de poder baseadas na opressão e exploração das mulheres, das crianças, dos sujeitos desprovidos do poder patriarcal. Esta relação alimenta as perversas desigualdades entre as diferentes idades, que, numa perspectiva adultocêntrica, hierarquiza concomitantemente a opressão que aliena as mulheres em sua condição de oprimida, fazendo reproduzir nos filhos a opressão que sofrem, do mesmo modo que o patrão faz nos homens, ou mesmo nas mulheres. A mulher exerce o poder na criança, em uma reprodução da ideologia

\footnotetext{
${ }^{9}$ No Portal Catarinas - projeto da mídia independente de jornalismo com a perspectiva feminista tem o convite para assistirmos, debatermos e divulgarmos o excelente documentário Gênero sob ataque (2019). Disponível em: https://catarinas.info/videos/assista-ao-documentario-genero-sob-ataque/_Acesso em: 30 jul. 2020.
} 
patriarcal por parte das mulheres, a opressão em cadeia, em uma síndrome do pequeno poder (SAFFIOTI, 2015, p. 68).

Outra contribuição importante de Saffioti nos enredamentos que envolvem as relações de gênero e a violência trata-se dos fios que entrelaçam o racismo e o sexismo que sustentam a sociedade de classes, em um novelo patriarcado-racismo-capitalismo (SAFFIOTI,2015,p.134) (2015, p. 134), com uma estrutura de poder que unifica as três ordens de produção de desigualdades e perversidades sistêmicas de gênero, de raça/etnia e de classe social.

Porém, perante o horror, como nos incita e inspira Conceição Evaristo (2008), escritora, professora aposentada, poeta, mulher negra, símbolo da resistência do potente feminismo negro brasileiro contemporâneo que, com sua poesia, nos afirma:

\section{NOITE NÃO ADOMERCE NOS OLHOS DAS MULHERES}

In memória de Beatriz do Nascimento ${ }^{10}$

A noite não adormece

nos olhos das mulheres

a lua fêmea, semelhante nossa,

em vigília atenta vigia

a nossa memória.

A noite não adormece

nos olhos das mulheres

há mais olhos que sono

onde lágrimas suspensas

virgulam o lapso

de nossas molhadas lembranças.

A noite não adormece

nos olhos das mulheres

vaginas abertas

retêm e expulsam a vida

donde Ainás, Nzingas, Ngambeles

e outras meninas luas

afastam delas e de nós

os nossos cálices de lágrimas.

A noite não adormecerá

jamais nos olhos das fêmeas

pois do nosso sangue-mulher

de nosso líquido lembradiço

em cada gota que jorra

um fio invisível e tônico

pacientemente cose a rede

de nossa milenar resistência.

\footnotetext{
${ }^{10}$ Para conhecer mais a respeito da trajetória intelectual de Beatriz do Nascimento - que também foi vítima de um feminicidio (foi morta pelo namorado agressor de uma amiga), "[...] mulher, negra, nordestina, migrante, professora, historiadora, poeta, ativista, pensadora”, ver texto de Alex Ratts, Prof. da UFG, coordenador do Núcleo de Estudos Africanos e Afro-Descendentes (NEAAD/UFG), autor do livro Eu sou Atlântica: sobre a trajetória de vida de Beatriz. Nascimento. Disponivel em: https://www.geledes.org.br/a-trajetoria-intelectual-ativista-de-beatriz-nascimento/ Acesso em: 10 maio 2020.
} 
Figura 3- Zapatos Rojos

\section{Elina Chauvet}

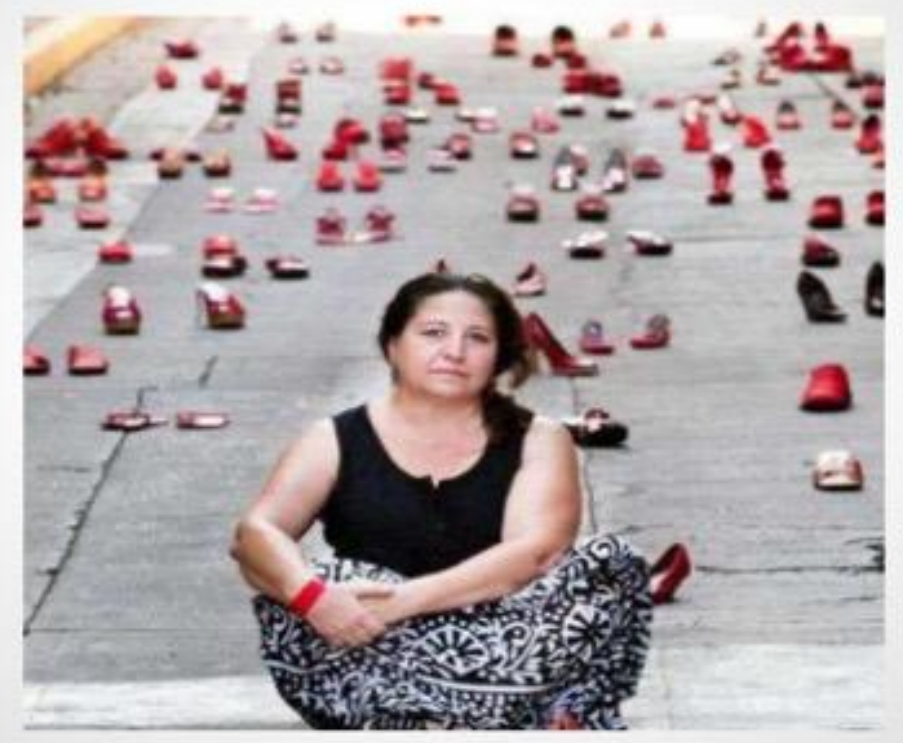

Elina Chauvet, artista plástica e arquiteta mexicana de 60 anos, espalhou centenas de sapatos vermelhos na Cidade do México. A intervenção procura conscientizar as autoridades locais sobre o alto número de feminícidios no país. Ela criou os "Zapatos Rojos” dez anos atrás, depois de a própria irmã ser assassinada pelo companheiro. Essa história se repete em diversos lugares do mundo e, por isso, percorre diversos países com o projeto. No México, esse tipo de crime cresceu 111\% nos últimos 4 anos. Em 2018, foram mais de 760 feminicídios, menos de 10\% desses casos foram resolvidos. Andrés Manuel López Obrador, presidente mexicano, se comprometeu a combater os crimes contra mulheres, mas, até agora, pouca coisa mudou ${ }^{11}$.

11 Fonte: https://catracalivre.com.br/cidadania/artista-espalha-sapatos-vermelhos-contra-o-feminicidio-no-mexico/ Acesso em: 01 ago. 2020. 
Figura 4- Poéticas da Resistência

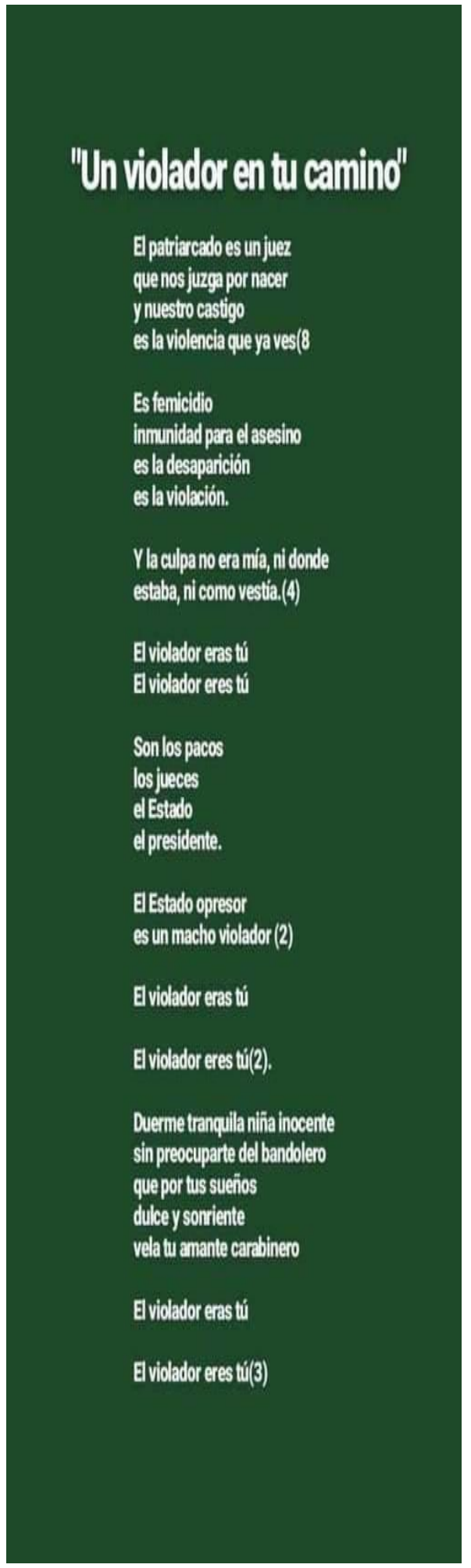

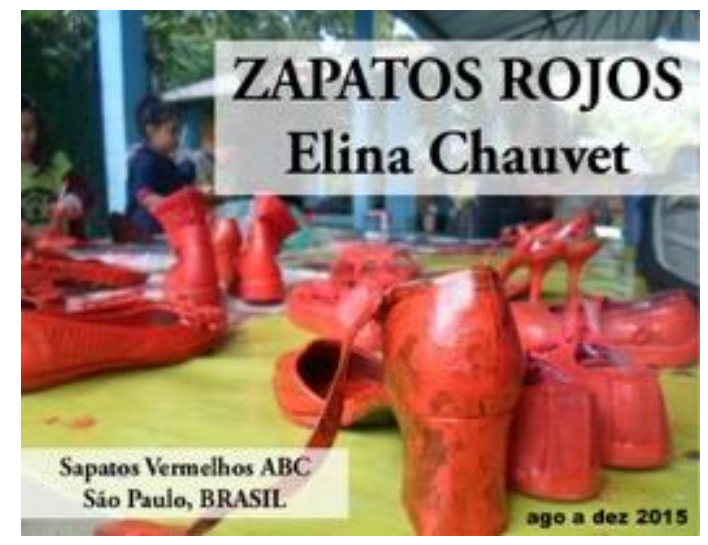
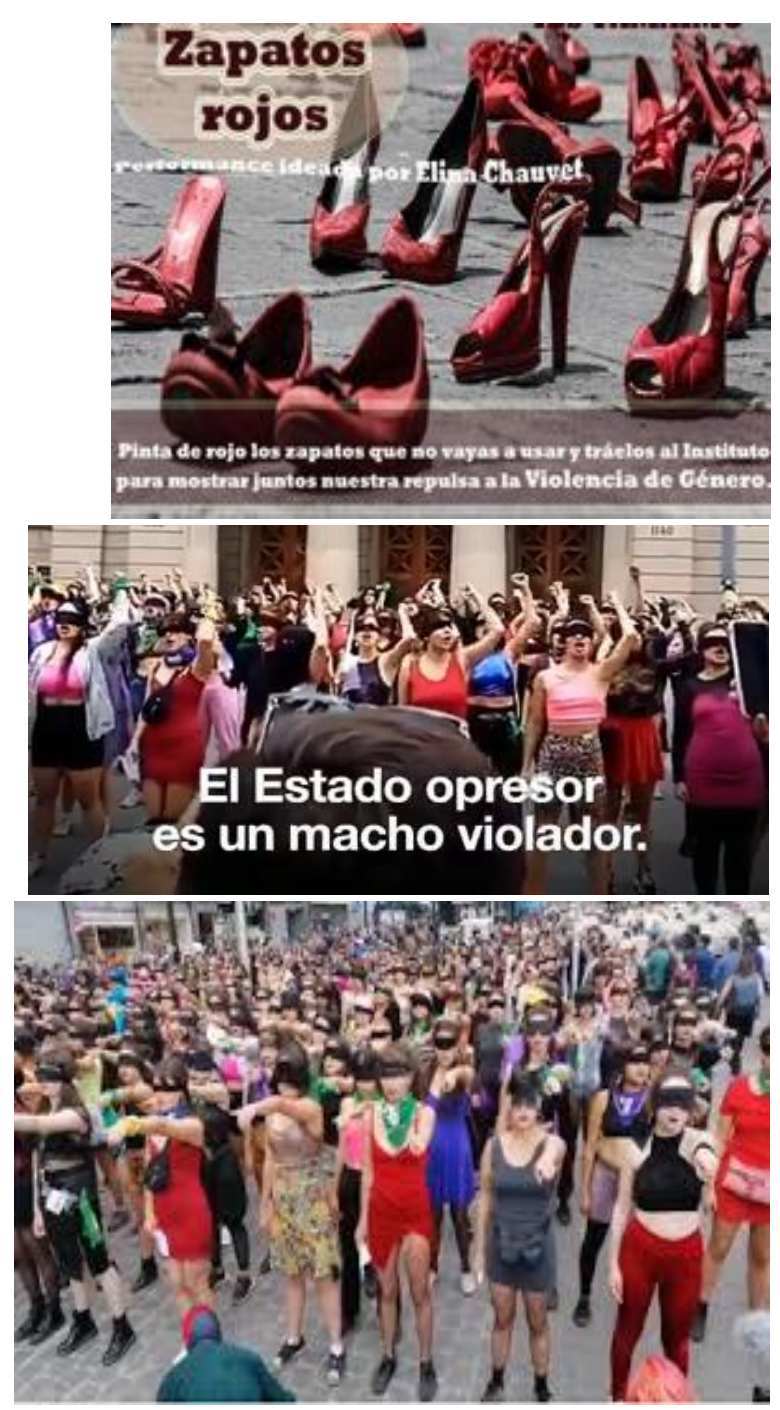

Mulheres chilenas viralizaram nas redes sociais com a performance feminista "Un Violador en Tu Camino", em português "Um estuprador em seu caminho". O protesto foi realizado pelo Coletivo LasTesis, em ação pelo Dia do Combate à Violência Contra a Mulher, em 25 de novembro. Centenas de mulheres se reuniram na Plaza de Armas, em Santiago.

O vídeo com o flash mob denuncia o machismo, o patriarcado e a cultura do estupro. 
Com vendas pretas nos olhos, as mulheres reproduzem uma coreografia ensaiada e entoam frases como "o estuprador é você". No refrão, o grito de protesto é ainda mais claro e afirma "o Estado opressor é um macho estuprador". A manifestação acontece em meio a crise que implodiu no Chile desde o último mês. Segundo informações da Revista Fórum, foram registrados cerca de 70 casos de abusos sexuais cometidos por policiais contra mulheres detidas. No instagram, o Coletivo LasTesis divulga novas convocatórias para que mulheres se reúnam em diversos locais no Chile. ${ }^{12}$

Figura 5- Ressonâncias feministas

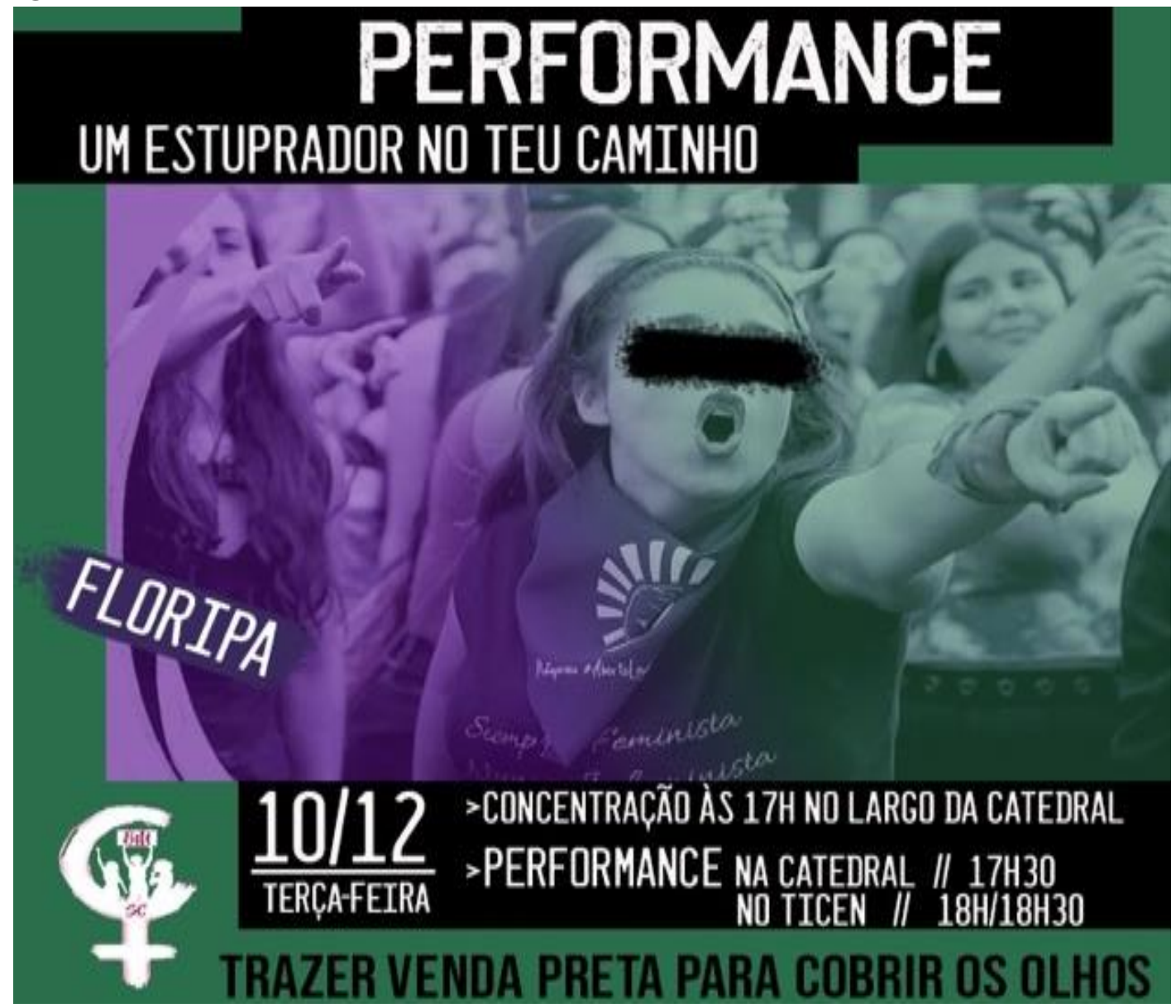

\section{Pedagogias descolonizadoras: antropofagia e politização}

$\mathrm{Na}$ tessitura da pesquisa, criação e atuação política alinhamo-nos contra as pedagogias da crueldade, partindo de um pressuposto feminista em que a creche é compreendida como locus privilegiado na construção de práticas de educação e cuidado descolonizadoras, embasadas em pedagogias emancipatórias.

A creche como espaço e tempo de direitos tem a criança pequena em sua centralidade, as mulheres em sua maioria docentes (com diploma e sem diploma), protagonistas ativas no combate a múltiplas formas de opressão, violência e discriminação,

12 Fonte: https://antropofagista.com.br/2019/11/28/video-estuprador-e-voce-performance-de-feministas-chilenascontra-o-estupro-viraliza Acesso em: 20 jul. 2020. 
evidenciando esse território na/da pequena infância como fundamental na vida contemporânea de muitas mulheres, permeado de contradições e possibilidades.

Inspiramo-nos em projetos do passado, como os parques infantis criados, dentre outros, por Mario de Andrade, em 1935, que são a origem da rede de Educação Infantil paulistana (FARIA, 1999):

Os parques infantis criados por Mário de Andrade em 1935 podem ser considerados como a origem da rede de educação infantil paulistana (FARIA,1995) - a primeira experiência brasileira pública municipal de educação (embora não-escolar) para crianças de famílias operárias que tiveram a oportunidade de brincar, de ser educadas e cuidadas, de conviver com a natureza, de movimentarem-se em grandes espaços e não em salas de aula. Lá produziam cultura e conviviam com a diversidade da cultura nacional, quando o cuidado e a educação não estavam antagonizados, e a educação, a assistência e a cultura estavam macunaimicamente integradas, no tríplice objetivo parqueano: educar, assistir e recrear. (FARIA, 1999,p. 61-62)

Em todo o Brasil encontramos redes municipais de Educação Infantil resistindo às políticas públicas neoliberais de privatização da educação. Florianópolis é uma das referências nacionais, pela qualidade e inovação, com unidades educativas que respeitam os direitos das crianças, envolvem as famílias, formam continuamente suas profissionais docentes, articulando pesquisas acadêmicas, práticas pedagógicas e políticas nacionais democráticas.

Nesta perspectiva, temos construído proposições concretas de formação continuada, alinhando pesquisas acadêmicas aos movimentos sociais, inspirando-se na metodologia do Fazendo Gênero/IEG - importante evento que ocorre periodicamente na Universidade Federal de Santa Catarina (UFSC), de produção crítico reflexiva, resistência política formativa e no princípio era a ação, tendo nas lutas das mulheres um potente princípio educativo para a profissionalização e politização docente na Educação Infantil e nos anos iniciais da Educação Básica.

Compreendemos que uma educação emancipadora prevê professoras/es e educadoras/es com o pensamento descolonizado, questionando todas as formas de autoritarismo e abolindo as formas de violência, atentas e "denunciando aspectos da educação sexista" e colonizadora, "evidenciando as estratégias de resistência que contribuem para a construção de uma educação mais igualitária no convívio das diferenças de idade, gênero, classe e raça.” (FINCO; GOBBI; FARIA, 2015)

É nessa direção que buscamos uma pedagogia da infância interseccional com perspectiva feminista (SILVA, 2020), que tenha em sua múltipla intencionalidade pedagógica a promoção de ações educativas por meio de intervenções artísticas - em diversas linguagens, mas especialmente as que problematizem as narrativas tradicionais dos contos de fadas (SILVA, 2018). Narrativas que se configuram como clássicos infantis mundiais e podem ser conectados com uma perspectiva de feminismo transnacional (SILVA; FARIA; FINCO, 2019), como chave à problematização das violências que perpassam as relações de gênero, buscando desconstruir estereótipos e normatizações de comportamentos entre homens/meninos e mulheres/meninas.

Questionamos nos processos formativos como vamos abolir todas as formas de violência se elas começam na reprodução de histórias machistas e em práticas violentas no 
espaço doméstico, em casa, com a tal "palmadinha que não dói", dada pela mãe e pelo pai? Como educar crianças feministas (ADICHIE, 2017) com as formas colonizadoras do adultocentrismo?

Astrid Lindgren (1907-2002), autora da personagem sueca transgressora Pippi Meia Longa, quando recebeu em 1978 o Prêmio da Paz dos editores alemães, apresentou o discurso Violência jamais, alertando as crianças para não obedecerem aos adultos sem que eles justificassem por que deveriam ser obedecidos. Como era a primeira vez que o prêmio era dado a uma autora de Literatura Infantil, ela perguntava: "Será que tem um defeito de fabricação na espécie humana já que recorremos sempre à violência?" (LINDGREN, $1978)^{13}$

Inspiradas pelas contemporâneas lições das jovens meninas-mulheres (SILVA, 2002) dos movimentos feministas, do coletivo chileno Las Tesis a diversas experiências pelo mundo, conjugando ações de ativismo político com educação, problematizando as violências de gênero e criando poéticas da resistência, enfatizamos o quanto estas questões podem compor entre as(os) pesquisadoras/es, professoras/es e demais docentes com/sem diploma nos processos coletivos de resistência do luto à luta, sobretudo no campo da infância, um processo de construção de uma educação antiautoritária, emancipadora, antiadultocêntrica desde a creche, desde o nascimento e na contramão das falácias da ideologia de gênero. (SANTIAGO; FARIA, 2018).

Por fim, acreditamos que tecemos neste ensaio um percurso reflexivo do luto à luta - bistoriográfico terapêutico, com foco em evidenciar as denúncias da crueldade sistêmica que nos atormentam, incorporando os demônios ${ }^{14}$, como nos incita Eduardo Galeano, com sua vitamina $\mathrm{E}$ (de estarmos com os deuses no corpo), e concomitantemente visualizando as resistências, no direito ao delírio de compreendermos este estado do mundo grávido de outro mundo.

Aqui buscamos focar nos caminhos de possibilidades com interlocuções e resistências transnacionais, de um Feminismo para os 99\% (ARRUZA, 2019) nas convocatórias feministas em aberto por todo planeta, das greves do 8 de março por melhores condições de trabalho, da Jornada Internacional de eliminação da Violência contra a Mulher, realizada mundialmente no dia 25 de novembro, que tem como alegoria a instalação dos Sapatos Vermelhos aos corpos femininos que gritam em aliança na performance coletiva de Um estuprador em seu caminho.

Chegando ao acaso absurdo das nossas re-existências em Pandemia, tendo no cenário político de contestação da realidade as manifestações em torno das Vidas Negras Importam, à chamada para o aniversário virtual de 41 anos de Marielle Franco, para não esquecermos da luta contra a impunidade em torno do seu feminicidio político ${ }^{15}$, como

\footnotetext{
${ }^{13}$ Conforme jaz discutido em Santiago e Faria (2018), Astrid no seu discurso: "Eu penso que se deve começar de baixo, das crianças...Quem é criança agora assumirá a direção do nosso mundo ... e deverá decidir as guerras, a paz e qual sociedade pretendem, se querem uma onde a violência só aumentará ou uma sociedade em que o ser humano viva em paz e fraternidade. Existe alguma esperança de que conseguirão criar um mundo mais pacífico do que nós fizemos?” (LINDGREN, op.cit., p. 17-18, tradução livre do italiano).

${ }^{14} \mathrm{O}$ escritor Eduardo Galeno, em um ensaio de 2005, publicado originalmente no site da revista Le Monde Diplomatique, discorre sobre as diferentes faces do demônio, na antítese de cada um desses 'anjos do mal' - Muçulmanos, judeus, mulheres, homossexuais, índios, negros, estrangeiros e pobres. Fonte: https://www.geledes.org.br/os-demonios-dodemonio-por-eduardo-galeano/ Acesso em: 01 ago.2020.

${ }^{15} \mathrm{O}$ feminicídio político de Marielle Franco. Fonte acessada em 01 ago.2020: (https://brasil.elpais.com/brasil/2019/03/14/politica/1552562116 307529.html).
} 
vem reivindicando a parlamentar Renata Souza, deputada estadual pelo PSOL, no RJ, que foi chefe de gabinete da vereadora Marielle e atualmente é pré-candidata à prefeitura do Rio de Janeiro.

Como epílogo, finalizamos com este belo movimento, político e poético das mulheres negras do luto à luta, junto à grande cantora Elza Soares, que, ao celebrar seus 90 anos em 2020, com seu corpo e voz potência, regrava com novos e modernos arranjos o clássico Juíro Final ${ }^{16}$, de Nelson Cavaquinho; que seus versos fiquem a ecoar em nossas utopias.

"O sol há de brilhar mais uma vez

A luz há de chegar aos corações

O mal será queimada a semente

O amor será eterno novamente

É o juízo final

A história do bem e do mal

Quero ter olhos pra ver

A maldade desaparecer"

Figura 6- Marielle Presente

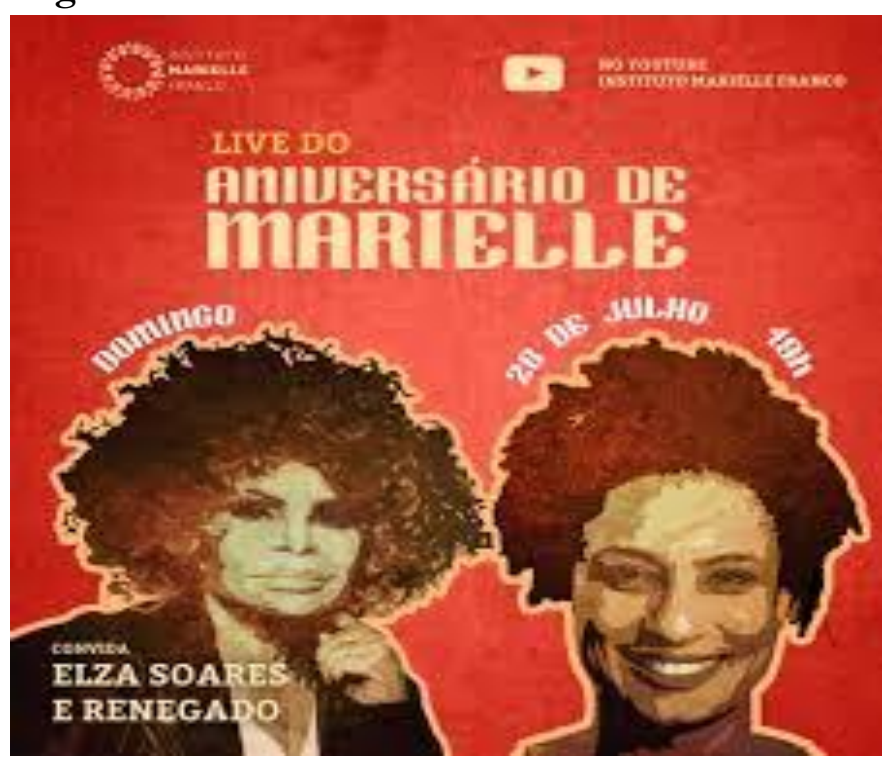

16 LiveElza porMarielle arrecadou recursos para que a família de Marielle e o Instituto continue lutando por justiça https://www.youtube.com/watch?v=CQHhSdRLZ74 Acesso em: 01 ago.2020. 
Figura 7- Elza soares Juizo Final

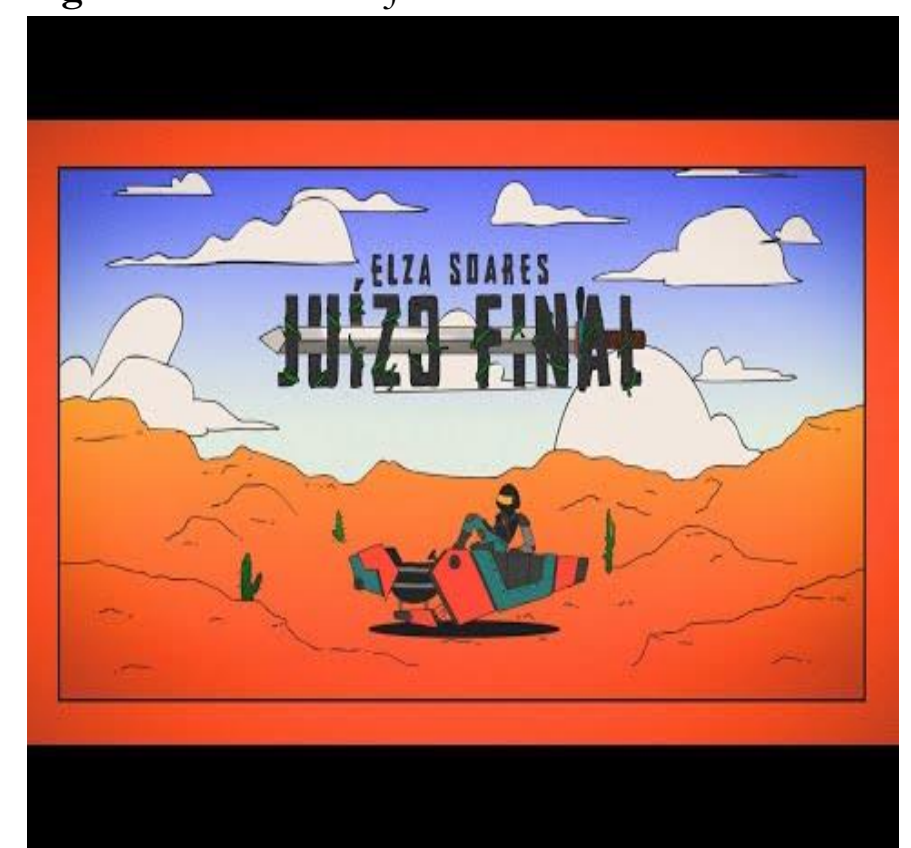

Imagens da live do Aniversário de Marielle ${ }^{17}$ e do clip de Elza Soares do clássico Juízo Final.

\section{Referências}

ADICHIE, Chimamanda N. Para educar crianças feministas: um manifesto. São Paulo: Cia das Letras, 2017.

ALMADA, Selva. Garotas Mortas. São Paulo: Todavia, 2018.

ARROYO, Miguel. Vidas Ameaçadas: exigências-respostas éticas da educação e da docência. Petrópolis: Vozes, 2019.

ARRUZA, Cinzia; BHATTACHARYA, Tithi; FRASER, Nancy. Feminismo para os 99\%: um manifesto. São Paulo: Boitempo, 2019.

BUTLER, Judith. Corpos em Aliança e a política das ruas: notas para uma teoria perfomativa da assembleia. Rio de Janeiro: Civilização Brasileira, 2019.

EVARISTO, Conceição. A noite não adormece nos olhos das mulheres. Cadernos Negros, Rio de Janeiro, v. 19, p. 26, jun. 2008.

FARIA, Ana Lúcia. G. de. A contribuição dos parques infantis de Mário de Andrade para a construção de uma pedagogia da educação infantil. Educ. Soc, Campinas, v. 20, n. 69, p. 60-91, dez. 1999. 17 O videoclipe com direção e animação de Pedro Hansen
(https://www.youtube.com/watch?v=VBU5MYaDKjo). Acesso em: 01 ago.2020. 
As origens da rede pública municipal de educação infantil na cidade de São Paulo. Proposições, Campinas,v. 6, n.17,p.34-45, dez.1995. (17), p. 34-45, 1995.

FEDERICI, Silvia. Mulheres e caça às bruxas: da Idade Média aos dias atuais. São Paulo: Boitempo, 2019.

Calibã e a Bruxa: mulheres, corpo e acumulação primitiva. São Paulo:

Elefante, 2017.

FINCO, Daniela; GOBBI, Marcia A.; FARIA, Ana Lúcia Goulart de. Creche e Feminismo: desafios atuais para uma educação descolonizadora. Campinas, SP: Edições Leitura Crítica; Associação de Leitura do Brasil - ALB; São Paulo: Fundação Carlos Chagas - FCC, 2015.

GALEANO, Eduardo. Mulheres. Porto Alegre: L\&PM, 2019.

hooks, bell. O feminismo é para todo mundo: políticas arrebatadoras. Rio de Janeiro: Rosa dos Tempos, 2018.

LINDGREN, Astrid. Mai violenza! Suécia: Salingon Förlag, Lidingö,1978.

MELO, Patricia. Mulheres Empilhadas. São Paulo: LeYa, 2019.

SAFFIOTI, Heleieth. Gênero patriarcado violência. São Paulo: Expressão Popular, 2015.

SANTIAGO, Flavio; FARIA, Ana. Lúcia Goulart de. Da descolonização do pensamento adultocêntrico à educação não sexista desde a creche: por uma pedagogia da não violência. In: TELES, M. A. A.; SANTIAGO, F.; FARIA, A. L. G. de. (orgs.) Por que a creche é uma luta das mulheres? Inquietações feministas já demonstram que as crianças pequenas são de responsabilidade de toda a sociedade! São Carlos: Pedro \& João Editores, 2018. p. 250-277.

SEGATO, Rita. L. Las nuevas formas de la guerra y el cuerpo de las mujeres. Revista Sociedade e Estado, v. 29, n. 2, p. 341-371, Brasilia, maio/ago. 2014.

La escritura en el cuerpo de las mujeres asesinadas en Ciudad Juárez.

Territorio, soberanía y crímenes de Segundo Estado. Buenos Aires: Tinta Limón, 2013. SILVA, Mauricio. R. Recordando e colando as imagens da vida cotidiana do trabalho e da cultura lúdica das meninas-mulheres e das mulheres-meninas da Zona da Mata Canavieira Pernambucana. In: FARIA, A. L. G. de. (org.) Infância e educação: As meninas.Cadernos Cedes, Campinas, ano XXII, n. 56, p. 23-52, abr. 2002.

SILVA, Adriana.A. Niunamenos: feminismo, pedagogias e poéticas da resistência. In: FINCO, Daniela; SILVA, Adriana A.; FARIA, Ana Lúcia de Goulart. (orgs.) Dossiê 
Feminismo em estado de alerta na educação de crianças pequenas em creches e préescolas. Revista Zero-a-Seis, Florianópolis, v. 20, p. 221-234, jan./jul. 2018.

SILVA, Adriana. A.; FARIA, A. L. G. de; FINCO, D. Lute como uma menina! O verbo é lutar deste o nascimento na vida de meninas e mulheres. In: ALVARENGA, M. S.; TAVARES, M. T.; MACHADO, R. F. (orgs.) Dossiê Rosa Luxemburgo, mulheres, liberdade e revolução. Revista Historiæ, Rio Grande, v. 10, n. 1, p. 59-82, fev. 2019.

SILVA, Adriana. A. Por uma educação infantil feminista: pedagogia, política e poéticas da resistência. In: BARREIRO, A.; CAVALCANTE, N. A. da S.; FARIA, A. L. G. de (orgs.) Pesquisas e pedagogias: educação para as diferenças. Uberlândia: Navegando Publicações, 2020. p. 203-219.

TELES, Maria Amélia de A. Breve história do feminismo no Brasil e outros ensaios. São Paulo: Editora Alameda, 2017.

\section{Filmografia}

QUEM MATOU ELOÁ. Direção: Lívia Perez. Produção: Doctela, Brasil: , 2015.

GÊNERO SOB ATAQUE. Direção: Jerónimo Centurión. Produção: Clacai (Consórcio Latino Americano Contra o Aborto Inseguro), Peru, Costa Rica, Colombia, Brasil, 2018. ILHA DAS FLORES. Direção: Jorge Furtado. Produção: Casa de Cinema de Porto Alegre, Brasil, 1989. 